\title{
The biodiversity of small passerine birds at wetlands: species loss and effects of climate change
}

\begin{abstract}
This research aims to analyse the biodiversity of small birds (passerines) and its trends in a Western Mediterranean semi-arid wetland by means of captures for ringing during fourteenyears (1991-2014). The palustrine species outnumbered non-palustrine in individuals but not in species. The diversity of passerines is about two-fifth parts of the total diversity of birds of the wetland. Fourteen-palustrine species outweigh as dominants in number and biomass, belonging to the family Acrocephalidae or Reed warblers. The heavyweight of non-palustrine species is exerted by a Leaf warbler, the Common Chiffchaff Phylloscopus collybita. The biodiversity falls significantly over time with losses of 0.072 nats per year. Similar trends identified for the richness, which leaves losses of 1 species per year, ranging from 9 to 10 species gains and losses for the overall passerine's assemblage. Diversity and richness correlate weakly and negatively with rainfall and positively with temperature, accounting from 15.1 to $20.4 \%$ of the variation in diversity of passerines, respectively. The loss of diversification of invertebrate preys due to global warming is considered a probable effect of the species decline.
\end{abstract}

Keywords: diversity, biomass, climatic change, passerines, trends, wetlands
Volume 2 Issue 3 - 2018

Ignacio Garcia Peiro

Department of Ecology \& Hydrology, University of Murcia, Spain

Correspondence: Ignacio García Peiró, Department of Ecology \& Hydrology, Faculty of Biology, University of Murcia, C/ El Salvador, 17-4D, 03203 Elche (Alicante), Spain, Tel (00)349654-51777, Fax (00)965-4213-20, Email ignacio.peiro@yahoo.es

Received: May 14, 2018 | Published: June 12, 2018

\section{Introduction}

Climatic change is already affecting many birds species in form of drifts of the departure or arrivals at their breeding areas, ${ }^{1,2}$ changing the populations dynamics, ${ }^{3}$ adaptations of the life cycle of migratory birds, ${ }^{4}$ changes in phenology, ${ }^{5}$ drifts in species distribution, ${ }^{6}$ changes in breeding outcomes, ${ }^{7}$ appearance of invaders and alien species which affect community patterns and population biology $\mathrm{y}^{8,9}$ or increase or shorten the range of distribution of species ${ }^{6,10-13}$ which provides a new global scenario for avian species distribution. ${ }^{14}$

In birds linked to wetlands, transformations in the habitat appear to be the main factor of the diversity loss. ${ }^{15-17}$ Habitat disappearance in wetlands of SE Spain in the second half of past century produced losses of palustrine passerine species and decreases of about $10-80 \%$ of its effectives. ${ }^{18}$ This study intends to show up and to analyse the biodiversity of small birds (passerines) associated to wetlands in an internationally protected Spanish man-made swamp-wetland of $2500 \mathrm{Ha}$, during a temporal series of 14 years (1991-2004) trying to explore if the decline in its trends is due to the local climatic events as a proximate factor. In spite of time series deficit, the data may result very useful for future prospects, trying to establish plans for the management and conservation of reedbed passerine birds and their habitats. ${ }^{15,19}$

In view of the earlier, the following questions are established: 1) Which are the overall parameters measuring the biodiversity of the community of palustrine and non-palustrine passerines? 2) How is the trend of the biodiversity along years? 3) Which is the effect of climatic variations on the biodiversity at a local scale?

\section{Material and methods}

Data for the present study arises from different sources: 1) captures of passerines get by means of ringing protocols implemented by the author during 1991-2004 in "El Hondo Natural Park", an internationally man-made swamp-wetland protected as RAMSAR site of $2500 \mathrm{Ha}$ of surface placed in SE Spain $\left(38^{\circ} 42^{\prime} \mathrm{N} 00^{\circ} 31^{\prime} \mathrm{W}\right)$ and representative of wetlands of semiarid and fragmented landscapes in the Western Mediterranean. Diversity indexes of palustrine species and non-palustrine were measured separately by alpha's Shannon's Wienner Index expressed in nats ${ }^{20}$ and a comprehensive value representing the biodiversity of total passerines (Appendix 1). Maximum bird's biodiversity of the wetland is calculated as $\log _{e} \mathrm{~N}$ $(\mathrm{N}=$ Number of all avian species listed for the Hondo Natural Park by). ${ }^{21}$ For the bird's bioenergetics, it was considered the biomass of passerines as the product of the number of total individuals of each species by the weight of a sample of birds of each species taken during ringing protocols. During these ringing schemes, each species was measured and accurately classified by means of general Spanish checklists $^{22}$ and European specific handbooks ${ }^{23}$ (Appendix 1). This is employed in other studies. ${ }^{24-27}$ Most ringing visits were carried out in the morning, when the bird's activity is higher ${ }^{28,29}$ but in some circumstances were conducted in the afternoon, so this might have influenced the probability of taking a less or more species in some years of research and some parameters of the community can have been thought influenced by wrong samples, however, dawn and evening sampling is found suitable for estimating the majority of reed passerines species..$^{30}$ Rarefaction extrapolations were not done. ${ }^{31}$ Annual indexes of diversity and a number of species (richness) were plotted against years of study (1991-2004) in order to check the decrease of the species' diversity along time (Figure 1). 2) Climatic variables are provided at a local scale (total amount of annual rainfall in mm and mean annual temperatures in ${ }^{\circ} \mathrm{C}$ ) correlated with diversification in order to determine the effect of climatic change on the diversity's trend. Non-parametric tests (Spearman correlations) and parametric (linear regressions) were achieved for these purposes using IBM SPSS v24 statistical package. ${ }^{32}$ 
Appendix I Systematic List of Passerines in “El Hondo” Natural Park (Alicante, SE Spain)

\begin{tabular}{|c|c|c|c|c|c|}
\hline Scientific name & English name & $\begin{array}{l}\text { Number of } \\
\text { individuals }\end{array}$ & $\begin{array}{l}\text { Individuals weigth (gr) } \\
\text { Mean } \pm S D(N)\end{array}$ & $\begin{array}{l}\text { Palustrine } \\
\text { status }\end{array}$ & $\begin{array}{l}\text { Biomass } \\
(\mathrm{gr})\end{array}$ \\
\hline $\begin{array}{l}\text { Hirundo rustica (Linnaeus, } \\
\text { I 758) }\end{array}$ & Barn Swallow & 5 & $18.6 \pm 1.7(5)$ & NP & 93.0 \\
\hline $\begin{array}{l}\text { Anthus pratensis (Linnaeus, } \\
\text { 1758) }\end{array}$ & Meadow Pipit & 4 & $16.5 \pm 0.7(2)$ & $P$ & 66.0 \\
\hline $\begin{array}{l}\text { Troglodytes troglodytes } \\
\text { (Linnaeus, I718) }\end{array}$ & Wren & 2 & $8.3 \pm 1.2(2)$ & NP & 16.6 \\
\hline $\begin{array}{l}\text { Erithacus rubecula (Linnaeus, } \\
\text { 1758) }\end{array}$ & Robin & 45 & $13.6 \pm 0.8(5)$ & NP & 612.0 \\
\hline $\begin{array}{l}\text { Luscinia megarhynchos (Brehm, } \\
1831 \text { ) }\end{array}$ & $\begin{array}{l}\text { Rufous } \\
\text { Nightingale }\end{array}$ & 7 & $20.5 \pm 2.2(5)$ & NP & 143.5 \\
\hline $\begin{array}{l}\text { Luscina svecica (Linnaeus, } \\
\text { 1758) }\end{array}$ & Bluethorat & 134 & $16.4 \pm 1.6(5)$ & $P$ & 2197.6 \\
\hline $\begin{array}{l}\text { Saxicola torquatus (Linnaeus, } \\
\text { 1766) }\end{array}$ & $\begin{array}{l}\text { Common } \\
\text { Stonechat }\end{array}$ & 24 & $13.1 \pm 0.9(5)$ & NP & 314.4 \\
\hline Turdus merula (Linnaeus, I758) & Blackbird & 7 & $79.0 \pm 4.2(2)$ & NP & 553.0 \\
\hline $\begin{array}{l}\text { Turdus philomelos (Brehm, } \\
\text { I83I) }\end{array}$ & Song Thrush & 3 & $68.0 \pm 0.0(1)$ & NP & 204.0 \\
\hline Cettia cetti (Temminck, I820) & Cetti's Warbler & 355 & $11.4 \pm 0.8(5)$ & $P$ & 4047.0 \\
\hline $\begin{array}{l}\text { Cisticola juncidis (Rafinesque, } \\
1810 \text { ) }\end{array}$ & Zitting Cisticola & 31 & $8.3 \pm 0.4(5)$ & $P$ & 257.3 \\
\hline $\begin{array}{l}\text { Locustella luscionoides (Savi, } \\
\text { |834) }\end{array}$ & Savi's Warbler & 20 & $15.7 \pm 1.5(5)$ & $P$ & 314.0 \\
\hline $\begin{array}{l}\text { Locustella naevia (Boddaert, } \\
\text { I 783) }\end{array}$ & $\begin{array}{l}\text { Grashopper } \\
\text { Warbler }\end{array}$ & I & $16.9 \pm 0.2(2)$ & $P$ & 16.9 \\
\hline $\begin{array}{l}\text { Acrocephalus melanopogon } \\
\text { (Temminck, 1823) }\end{array}$ & $\begin{array}{l}\text { Moustached } \\
\text { Warbler }\end{array}$ & 199 & $10.5 \pm 0.9(5)$ & $P$ & 2089.5 \\
\hline $\begin{array}{l}\text { Acrocephalus paludicola } \\
\text { (Vieillot, 1817) }\end{array}$ & Aquatic Warber & I & $10.0 \pm 0.7(2)$ & $P$ & 10.0 \\
\hline $\begin{array}{l}\text { Acrocephalus schoenobaenus } \\
\text { (Linnaeus, 1758) }\end{array}$ & Sedge Warbler & 13 & $1 \mathrm{I} .1 \pm 0.6(5)$ & $P$ & 144.3 \\
\hline $\begin{array}{l}\text { Acrocephalus scirpaceus } \\
\text { (Hermann, 1804) }\end{array}$ & Reed Warbler & 1832 & $10.4 \pm 0.4(5)$ & $P$ & 19052.8 \\
\hline $\begin{array}{l}\text { Acrocephalu arundinaceus } \\
\text { (Linnaeus, 1758) }\end{array}$ & $\begin{array}{l}\text { Great Reed } \\
\text { Warbler }\end{array}$ & 227 & $29.2 \pm 2.2(5)$ & $P$ & 6628.4 \\
\hline $\begin{array}{l}\text { Hippolais polyglotta (Vieillot, } \\
\text { 18I7) }\end{array}$ & $\begin{array}{l}\text { Melodious } \\
\text { Warbler }\end{array}$ & I & $9.4 \pm 0.0(1)$ & NP & 9.4 \\
\hline Sylvia undata (Boddaert, 1783) & Dartford Warbler & 1 & $8.6 \pm 0.7(2)$ & NP & 8.6 \\
\hline Sylvia cantillans (Pallas, 1764) & $\begin{array}{l}\text { Spectacled } \\
\text { Warbler }\end{array}$ & 4 & $9.2 \pm 0.2(3)$ & NP & 36.8 \\
\hline $\begin{array}{l}\text { Sylvia melanocephala (Gmelin, } \\
\text { 1788). }\end{array}$ & Sardinian Warbler & 47 & $11.2 \pm 0.3(5)$ & NP & 526.4 \\
\hline Sylvia borin (Boddaert, 1783) & Garden Warbler & 2 & $20.6 \pm 1.8(2)$ & NP & 41.2 \\
\hline $\begin{array}{l}\text { Sylvia atricapilla (Linnaeus, } \\
\text { 1758) }\end{array}$ & Blackcap & 59 & $18.3 \pm 2.5(5)$ & NP & 1079.7 \\
\hline $\begin{array}{l}\text { Phylloscopus collybita (Vieillot, } \\
\text { 1817) }\end{array}$ & $\begin{array}{l}\text { Common } \\
\text { Chiffchaff }\end{array}$ & 1152 & $7.4 \pm 0.6(5)$ & NP & 8524.8 \\
\hline & Willow Warbler & 17 & $9.1 \pm 0.5(5)$ & NP & 154.7 \\
\hline $\begin{array}{l}\text { Panurus biarmicus (Linnaeus, } \\
\text { I 758) }\end{array}$ & Bearded Tit & 198 & $13.2 \pm 0.6(5)$ & $P$ & 2613.6 \\
\hline $\begin{array}{l}\text { Remiz pendulinus (Linnaeus, } \\
\text { 1758) }\end{array}$ & Penduline Tit & 33 & $9.2 \pm 0.6(5)$ & $P$ & 303.6 \\
\hline Parus major (Linnaeus, I758) & Great Tit & 4 & $17.6 \pm 0.6(3)$ & NP & 70.4 \\
\hline $\begin{array}{l}\text { Lanius meridionalis (Temminck, } \\
\text { 1830) }\end{array}$ & $\begin{array}{l}\text { Southern Grey } \\
\text { Shrike }\end{array}$ & 2 & $62.5 \pm 3.6(2)$ & NP & 125.0 \\
\hline $\begin{array}{l}\text { Passer domesticus (Linnaeus, } \\
\text { 1758) }\end{array}$ & Common Sparow & 9 & $28.1 \pm 1.2(3)$ & NP & 252.9 \\
\hline $\begin{array}{l}\text { Passer montanus (Linnaeus, } \\
\text { I } 758 \text { ) }\end{array}$ & Tree Sparrow & 1 & $17.3 \pm 0.0(I)$ & NP & 17.3 \\
\hline $\begin{array}{l}\text { Fringilla coelebs (Linnaeus, } \\
\text { 1758) }\end{array}$ & $\begin{array}{l}\text { Common } \\
\text { Chaffinch }\end{array}$ & 16 & $20.1 \pm 2.1(4)$ & NP & 321.6 \\
\hline $\begin{array}{l}\text { Serinus serinus (Linnaeus, } \\
\text { 1758) }\end{array}$ & European Serin & 7 & $10.8 \pm 0.5(4)$ & NP & 75.6 \\
\hline
\end{tabular}




\begin{tabular}{|c|c|c|c|c|c|}
\hline Scientific name & English name & $\begin{array}{l}\text { Number of } \\
\text { individuals }\end{array}$ & $\begin{array}{l}\text { Individuals weigth (gr) } \\
\text { Mean } \pm S D(N)\end{array}$ & $\begin{array}{l}\text { Palustrine } \\
\text { status }\end{array}$ & $\begin{array}{l}\text { Biomass } \\
\text { (gr) }\end{array}$ \\
\hline $\begin{array}{l}\text { Carduelis carduelis (Linnaeus, } \\
\text { I758) }\end{array}$ & Goldfinch & 5 & $15.0 \pm 0.6(2)$ & NP & 75.0 \\
\hline $\begin{array}{l}\text { Carduelis chloris (Linnaeus, } \\
\text { 1758) }\end{array}$ & Greenfinch & 5 & $22.9 \pm 1.3(3)$ & NP & 114.5 \\
\hline $\begin{array}{l}\text { Emberiza schoeniclus } \\
\text { (Linnaeus, I758) }\end{array}$ & Reed Bunting & 31 & $\mid 7.7 \pm 1.4(5)$ & $P$ & 548.7 \\
\hline Total samples & & 417 & & & \\
\hline Total Individuals & & 4504 & & & \\
\hline Total Passerine species & & 37 & & & \\
\hline Total palustrine species & & 14 & & & \\
\hline Total non palustrine species & & 23 & & & \\
\hline $\begin{array}{l}\text { Number of palustrine's } \\
\text { individuals }\end{array}$ & & 2945 & & & \\
\hline $\begin{array}{l}\text { Number of non palustrine's } \\
\text { individuals }\end{array}$ & & 1559 & & & \\
\hline Total Diversity (nats) & & 1.919 & & & \\
\hline Palustrine's diversity & & 1.253 & & & \\
\hline Non-Palustrine's diversity & & 0.665 & & & \\
\hline Total Biomass (gr) & & 51660 & & & \\
\hline Palustrine's biomass & & 38290 & & & \\
\hline Non-Palustrine's biomass & & 13370 & & & \\
\hline
\end{tabular}

\section{Results}

The rainfall weakly tended to rise a long time and temperatures dropped in 1991-2004 period (Spearman $\mathrm{r}=0.20$, $\mathrm{p}=0.493$; temperatures: $\mathrm{r}=-0.27$; $\mathrm{p}=0363)$. By using long temporal dataset of 19 years (1991-2009) it is found a stronger significant increase of rainfall (Spearman $\mathrm{r}=0.50 ; \mathrm{p}=0.029$ ) and a weak increase of temperatures $(\mathrm{r}=0.29 ; \mathrm{p}=0.224)$.

The entire number of passerine species was 37. The palustrine species (14) outnumbered non-palustrine in individuals but not in species (Appendix 1), so its diversity (1.26) is $66 \%$ of total passerines diversity and is about two fifth parts $(37 \%)$ of the overall diversity of birds of the wetland (5.15) taking into account the full number of bird species of El Hondo Natural Park $(\mathrm{N}=172) .{ }^{21}$ The rate of palustrine species is $38 \%$. Only a few palustrine species refer to the family Acrocephalidae or Reed warblers which are Afrotropical passerines present largely in summer or migratory periods ${ }^{33,34}$ and exceeded in quantity and biomass as dominants (Appendix 1). The heavyweights of non-palustrine species (Appendix 1) was wielded by tiny Leaf warblers as Common Chiffchaff (Phylloscopus collybita). ${ }^{35}$ This is an opportunistic palustrine in winter in southern temperate areas of Western Palearctic ${ }^{36}$ but in breeding northern areas establish in mature lowland woodlands, ${ }^{37}$ so was not considered belonging palustrine in the community here analyzed (Appendix 1). Both species suppose $70 \%$ of the absolute biomass of passerines (Appendix 1).

The biodiversity (Figure 2) falls significantly along time for nonpasserines and total passerines while palustrine passerines showed a tendency to decrease. Similar trends are found for the richness of species (Figure 1). The rainfall correlates weakly and negatively with diversity and positively with temperature, so when rainfall increases, diversity reduces while it grows in parallel with temperatures. The percentage of variation in diversity of non-palustrines exerted by rainfall $\left(r^{2}=0.204\right.$, Figure 2$)$ is the biggest determinant of change in diversity jointly with the variation in diversity of palustrine exerted by temperatures $\left(r^{2}=0.151\right.$, Figure 2$)$. Linear regression among number of species on year resulted to be highly negatively significant and to be the determinant of the variation of species richness, giving losses of one species by year with a range between -10 and 9 of losses and gains in the total assemblage (Species $=-1.413 *$ Year+2838.484; $\mathrm{F}_{1,13}=16.782, \mathrm{p}<0.001, \mathrm{r}^{2}=0.583$; Figure 1$)$.

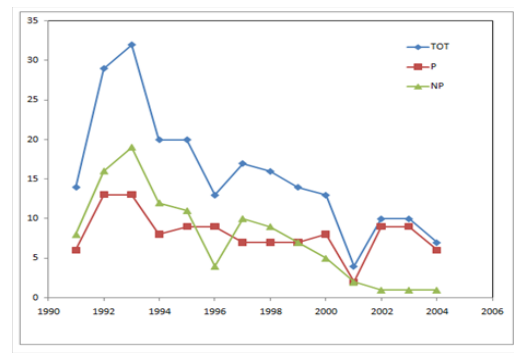

Figure I Evolution of richness of palustrine species (P), non-palustrine (NP) and total palustrine (TOT) from 1991-2004. Spearman correlations (palustrine: $r=-0.307 ; p=0.286$; non-palustrine: $r=-0.845 ; p=0.001$; total species: $r=-0.815 ; p=0.001$ ).

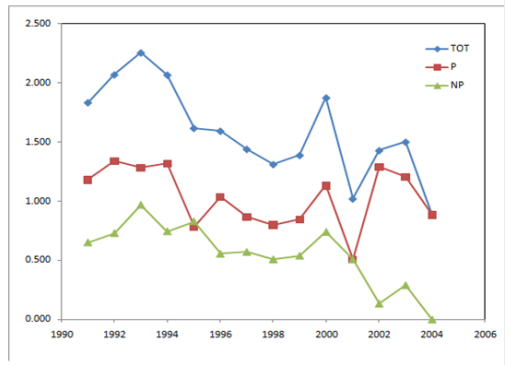

Figure 2 Trends in Shannon's wiener diversity, expressed in nats, for palustrine $(\mathrm{P})$, non-palustrine (NP) species and total palustrine diversity (TOT) from I99I to 2004. Spearman correlations (palustrine: $r=-0.305$; $p=0.288$; non-palustrine: $r=-0.780 ; p=0.001$; total diversity: $r=-0.745 ; p=0.002$ ). 


\section{Discussion}

The results of this study essentially point out that the El Hondo Natural Park is a wetland relatively impoverished in biodiversity of passerines but valuable in reed-bed bird specialists or palustrine species, representative of the true assemblage. In general terms this is a poor passerine's community with a global diversity index in the inner bound found for Shannon's Index of 1.5 to $3.5^{38}$ or from 1.8 to 5.3 for bird's communities ${ }^{39}$ and enters in the range of diversity (1.6-2.1) of Mediterranean reed-marsh communities..$^{25,40-44}$ Only two species, the Eurasian Reed Warbler (Acrocephalus scirpaceus) and the Common Chifffchaff (Phylloscopus collybita) suppose seven-parts of the total biomass of passerine community, illustrating the heavyweights of the assemblage.

It was found a negative effect of rainfall on the diversity, but a positive effect of temperatures on the fourteen years period (19912004). Longer temporal climatic datasets offer a rising of temperatures by the effect of climate change and this could have an effect in the diversity of palustrines by producing a fall in the non-palustrines diversity. In fact, long-temporal series of nineteen years (1991-2009) offer a non-significant increment of temperatures and significant increment of rainfall. The ecosystem gains and losses in a range of 9-10 species per year. This involves a great variation in passerine's assemblage and harsh effects for its biodiversity. Other studies find that the number and proportion of long-distance migrants decrease with increasing winter temperature, decreasing spring temperature, and increasing spring precipitation..$^{45}$ Over a 13 -year period of warming temperatures, diversity indices increased while average community specialization decreased according to other studies. ${ }^{46}$ Habitat specialists and cold-associated species showed consistently more negative effects of higher temperatures than habitat generalists and southerly distributed species associated with warm temperatures. ${ }^{47}$ The potential explanations of decline of species in El Hondo may be the loss of potential preys available, mostly Midges Chironomidae the most essential part of the diet of Common Chiffchaffs (Phylloscopus collybita) in El Hondo Natural Park ${ }^{48}$ and Beetles (Coleoptera) the gross for Acrocephalidae and Cettidae diet in wetlands of Western Iberia. ${ }^{49,50}$ In this form, climatic change can facilitate the extinction of invertebrates or modifications in its phenology $y^{51,52}$ which in turn can alter trophic interactions of the ecosystems..$^{53,54}$

\section{Acknowledgments}

I thank Ministerio Medio Ambiente (Madrid) for permissions to use metallic-numbered rings and Comunidad de Riegos de Levante for giving me access to property and Generalitat Valenciana for permissions to ring in El Hondo Natural Park.

\section{Conflict of interest}

Author declares that there is no conflict of interest.

\section{References}

1. Jenni L, Kéry M. Timing of autumn bird migration under climate change: advances in long-distance migrants, delays in short-distance migrants. Proceedings of the Royal Society of London B: Biological Sciences. 2003;270(1523):1467-1471.

2. Schaefer HC, Jetz W, Böhning-Gaese K. Impact of climate change on migratory birds: community reassembly versus adaptation. Global Ecology and Biogeography. 2008;17(1):38-49.
3. Sillett T, Scott R, Holmes T, et al. Impacts of a global climate cycle on population dynamics of a migratory songbird. Science. 2000;288(5473):2040-2042.

4. Coppack T, Both C. Predicting life-cycle adaptation of migratory birds to global climate change. Ardea. 2002;90:369-378.

5. Cotton PA. Avian migration phenology and global climate change. Proceedings of the National Academy of Sciences. 2003;100(21):12219-12222.

6. Parmesan C. Climate and species' range. Nature. 1996;382:765-766.

7. Visser ME, Van Noordwijk AJ, Tinbergen JM, et al. Warmer springs lead to mistimed reproduction in great tits (Parus major). Proceedings of the Royal Society of London B: Biological Sciences. 1998;265(1408):1867-1870.

8. Levine JM. Species diversity and biological invasions: relating local process to community pattern. Science. 2000;288(5467):852-854.

9. Sakai AK, Allendorf FW, Holt JS, et al. The population biology of invasive species. Annual review of ecology and systematics. 2001;32:305-332.

10. Ferrer X. On the presence of the Azure-winged Magpie (Cyanopica cyana) in the northeastern corner of the Iberian Peninsula. Ardeola. 1987;34(1):110-113.

11. Sánchez-Lafuente AM, Rey P, Valera F, et al. Past and current distribution of the Purple Swamphen Porphyrio porphyrio L. in the Iberian Peninsula. Biological Conservation. 1992;61(1):23-30.

12. Valera F, Rey P, Sánchez-Lafuente AM, et al. The Situation of Penduline Tit (Remiz pendulinus) in Southern Europe: A new stage of its expansion. Journal of Ornithology. 1990;131(4):413-420.

13. Huntley B, Green RE, Collingham YC, et al. A climatic atlas of European breeding birds. Lynx Edicions, Barcelona; 2007.

14. Hagemeijer EJM, Blair MJ. The EBCC Atlas of European Breeding Birds: their distribution and abundance. T \& AD Poyser, London; 1997.

15. Peiró IG. Estudios ornitológicos basados en la gestión del hábitat de los Passeriformes del carrizal en el Parque Natural de El Fondo (Alicante, SE de España). University of Murcia; 2006.

16. Jetz W, Wilcove DS, Dobson AP. Projected impacts of climate and land-use change on the global diversity of birds. PLoS biology. 2007;5(6):e157.

17. Raquel AJ. Patterns of Duck Community Composition in the Prairie Pothole Region of Canada: Effects of Climate and Land Use. University of Saskatchewan; 2017.

18. Paracuellos M. Effects of long-term habitat fragmentation on a wetland bird community. Revue d'Ecologie (Terre et Vie). 2008;63(3):227-238.

19. Peiró IG. The importance of the management of small reed patches for the conservation of endangered Passerine birds linked to wetlands. Forest Res Eng Int J. 2017;1(2):70-72.

20. Magurran AE. Ecological diversity and its measurement. Princeton University Press; 1989.

21. Navarro Medina JD. Estudio ornitológico de El Hondo. Caja de Ahorros del Mediterráneo, Alicante; 1988.

22. Bernis F. Prontuario de la avifauna española. Ardeola. 1954;1:11-85.

23. Svensson L. Identification guide to European passerines. Stockholm; 1992. p. 368.

24. Blondel J. Méthodes de dénombrement des populations d'oiseaux. In; Lamotte M, Bourliere F, editors. Problème d'écologie. Masson \& Cie Paris; 1969. p. 97-151. 
25. Esquivias JA, Cádenas AM, Bach C. Estudio de la comunidad de Paseriformes de la laguna de Zoñar (Córdoba, España). Naturalia Hispanica. $1983 ; 24: 29-34$.

26. Dolton CS, Brooke ML. Changes in the biomass of birds breeding in Great Britain, 1968-88. Bird Study. 1999;46(3):274-278.

27. Little IT, Hockey PA, Jansen R. Assessing biodiversity integrity for the conservation of grazed and burnt grassland systems: avian field metabolic rates as a rapid assessment tool. Biodiversity and Conservation. 2015;24(6):1443-1471.

28. Bruni A, Mennill DJ, Foote JR. Dawn chorus start time variation in a temperate bird community: relationships with seasonality, weather, and ambient light. Journal of Ornithology. 2014;155(4):877-890.

29. Farina A, Ceraulo M, Bobryk C, et al. Spatial and temporal variation of bird dawn chorus and successive acoustic morning activity in a Mediterranean landscape. Bioacoustics. 2015;24(3):269-288.

30. Trnka A, Szinai P, Hošek V. Daytime activity of reed passerine birds based on mist-netting. Acta Zool Acad Sci Hung. 2006;52(4):417-425.

31. Tipper JC. Rarefaction and rarefiction - the use and abuse of a method in paleoecology. Paleobiology. 1979;5(4):423-434.

32. SPSS Inc. SPSS Reference Guide. SPSS Inc. Chicago; 2000.

33. Kennerley P, Pearson D. Reed and Bush Warblers. Christopher Helm. London; 2010.

34. Leisler B, Schulze-Hagen K. The reed warblers. Diversity in a uniform bird family. KNNV Publishing, Zeist; 2011.

35. Baker K. Warblers of Europe, Asia and North Africa. Christopher Helm, London; 1997.

36. Cramp S, editor. The Birds of the Western Palearctic. Vol VI. Oxford University Press. Oxford; 1992.

37. Tellería JL, Asensio B, Díaz M. Aves Ibéricas. II. Paserifomes. Reyero JM, editor. Madrid; 1999

38. Margalef R. Homage to Evelyn Hutchinson, or why there is an upper limit to diversity. Connect Acad Arts Sci. 1972;44:211-235.

39. Orians GH. On the evolution of mating systems in birds and mammals. The American Naturalist. 1969;103(934):589-603.

40. Paracuellos M. Análisis comparativo entre las comunidades de Passeriformes de cañaverales y carrizales en el sureste ibérico. Ardeola. 1997;44(1):105-108.
41. Villarán A. Evolución estacional de la comunidad de aves de carrizal de Villamejor (España central), a partir de datos de anillamiento. Oxyura: Revista sobre las zonas húmedas. 2000;10(1):137-152.

42. Moreno CAT. La comunidad de paseriformes en un carrizal de la Mancha húmeda. Revista de anillamiento. 2007;19:10-18.

43. Arizaga J, Azkona A, Unamuno E. Evolución estacional del ensamblado de aves paseriformes en dos carrizales del área cantábrica: el caso de Urdaibai (costa vasca). Revista Catalana de Ornitologia. 2013;29:49-59.

44. Vera P, Giménez ME. Colonización y evolución inicial de la comunidad de paseriformes en un humedal restaurado del Este de la península ibérica. Revista de anillamiento. 2013;31:61-72.

45. Lemoine N, Böhning-Gaese K. Potential impact of global climate change on species richness of long-distance migrants. Conservation Biology. 2003;17(2):577-586.

46. Davey CM, Chamberlain DE, Newson SE, et al. Rise of the generalists: evidence for climate driven homogenization in avian communities. Global Ecology and Biogeography. 2012;21(5):568-578.

47. Albright TP, Pidgeon AM, Rittenhouse CD, et al. Effects of drought on avian community structure. Global Change Biology. 2010;16(8):2158-2170.

48. López-Iborra GM, Limiñana R, García Peñarrubia S, et al. Diet of Common Chiffchaffs Phylloscopus collybita wintering in a wetland in southeast Spain. Revista Catalana d'Ornitologia. 2005;21:29-36.

49. Cárdenas AM, Torres JA, Bach C. Estudio comparado del régimen alimentario de Acrocephalus arundinaceus y A. scirpaceus en la Laguna de Zóñar. Ardeola. 1984;30(1):33-44.

50. Araújo PM, Lopes PB, da Silva LP, et al. The Importance of Reedbeds and Riparian Areas for Cetti's Warbler Cettia cetti throughout its Annual Cycle. Wetlands. 2016;36(5):875-887.

51. Volney WJA, Fleming RA. Climate change and impacts of boreal forest insects. Agriculture, Ecosystems \& Environment. 2000;82(13):283-294.

52. Stefanescu C, Penuelas J, Filella I. Effects of climatic change on the phenology of butterflies in the northwest Mediterranean Basin. Global Change Biology. 2003;9(10):1494-1506.

53. Harrington R, Woiwod I, Sparks T. Climate change and trophic interactions. Trends in Ecology \& Evolution. 1999;14(4);146-150.

54. Voigt W, Perner J, Davis AJ, et al. Trophic levels are differentially sensitive to climate. Ecology. 2003;84(9):2444-2453. 